\title{
Cordonnier Grade 2 Infectious Symptom Requiring Inpatient Management
}

National Cancer Institute

\section{Source}

National Cancer Institute. Cordonnier Grade 2 Infectious Symptom Requiring Inpatient

Management. NCl Thesaurus. Code C138317.

Any infectious symptom requiring inpatient management. 